\title{
Igreja presente e atuante no mundo: interpretação da proposta de "cristianismo arreligioso" de Dietrich Bonhoeffer à luz do conjunto de sua teologia
}

\author{
Orientadora: Maria Teresa de Freitas Cardoso \\ Doutorando: Marco Antonio Santos \\ Área de Concentração: Teologia Sistemático-Pastoral \\ Linha de Pesquisa: Religião e Modernidade \\ Projeto de Pesquisa: Questões sobre a Igreja e os diálogos
}

A razão para a presença da Igreja no mundo está intimamente ligada à missão de Deus através Cristo. Sua relevância será decorrente de sua decisão em assumir participar do compromisso de Cristo. Dietrich Bonhoeffer demonstra através de sua vida e de sua teologia esse comprometimento de forma irrevogável. Para ele, Cristo não viveu para si, mas ilumina com sua existência para os outros o caminho a ser percorrido pela Igreja. O discipulado é o seguimento de Cristo também nessa prática. A religião, quando mal compreendida, ou quando se limita a pensar em Deus como "Deus ex machina", como recurso ao qual se relegam os problemas, pode obscurecer o caminho da Igreja, razão pela qual emerge das reflexões de Bonhoeffer na prisão a proposta de um "cristianismo arreligioso". Longe de pretender suprimir a religião ou negar a fé em Deus, Bonhoeffer busca a visibilidade da verdadeira religião através da qual Cristo se faz presente no mundo. Ele percebe que no mundo que se tornou adulto a Igreja deve sair da indiferença e assumir suas responsabilidades e, à semelhança de Cristo, "estar aí para os outros" através de uma nova linguagem e uma presença atuante no mundo, posicionando-se contra as injustiças e os sofrimentos, comunicando a mensagem libertadora de Jesus de Nazaré, que é uma mensagem de amor.

Palavras-chave: Igreja. Comunhão. Responsabilidade. 